Check for updates

The BMJ

kabbasi@bmi.com Follow Kamran on Twitter@KamranAbbasi Cite this as: BMJ 2021;374:n1945 http://dx.doi.org/10.1136/bmj.n1945 Published: 05 August 2021

\title{
A new leader for the NHS in its summer of discontent
}

\section{Kamran Abbasi executive editor}

Amanda Pritchard is the new chief executive officer of NHS England and the first woman to lead the organisation (doi:10.1136/bmj.n1930), ${ }^{1}$ joining female health service chief executives in Northern Ireland and Scotland. Pritchard is an experienced NHS senior manager, a success story of the NHS graduate training scheme, and an admirer of Elizabeth I, the last Tudor monarch, whom she describes as a "strong leader in a male world" (https://www.thetimes.co.uk/article/amanda-pritchard-the-new-nhs-chief-my-heroelizabeth-i-a-strong-leader-in-a-male-worldhq2gjfs7f). ${ }^{2}$ Considering some of the more political alternatives that were discussed, Pritchard's appointment is being welcomed, albeit with an eye on how much "autonomy she is afforded" (doi:10.1136/bmj.n1916).

The NHS was recently awarded the George Cross, the UK's highest civilian gallantry award, for 73 years of "dedicated service" and for the "courageous efforts" of health professionals during the covid-19 pandemic (doi:10.1136/bmj.n1917). ${ }^{4}$ A new review by the Royal College of Physicians judged hospitals' care of patients with covid to be excellent, good, or adequate in $96.5 \%$ of cases (doi:10.1136/bmj.n1935). ${ }^{5}$

Yet the health service remains under a degree of strain perhaps not seen since its inception in 1948 (doi:10.1136/bmj.n1917). ${ }^{4}$ Primary care is "running on empty" through unseasonal demand and workforce shortages (doi:10.1136/bmj.n1915; doi:10.1136/bmj.n1913). ${ }^{67}$ The mandatory vaccination of staff in social care is leading to debate about its value and concerns about staff leaving (doi:10.1136/bmj.n1903; doi;10.1136/bmj.n1921; doi:10.1136/bmj.n1902). ${ }^{8-10}$ Socioeconomic impacts on life expectancy, in this case with evidence of poor outcomes in white people (doi:10.1136/bmj.n1886), ${ }^{11}$ a growing burden of long term conditions such as diabetes, depression, and dementia (doi:10.1136/bmj.n1651; doi:10.1136/bmj.n1449; doi:10.1136/bmj.n1661; doi:10.1136/bmj.n1779),, ${ }^{12-15}$ and later years of life marked by worsening mobility (doi:10.1136/bmj.n1743), ${ }^{16}$ underline the importance of the NHS being more than a hospital service.

The "new normal" depends on innovation, such as use of teleconsultations and virtual team meetings in cardiovascular services, and better integration between primary, secondary, and social care (doi:10.1136/bmj.n1861). ${ }^{17}$ But innovation, a prominent feature of Pritchard's statement of intent (https://twitter.com/AKPritchard2/sta-

tus/1422239492359041024), ${ }^{18}$ is no panacea and can become a front for cost cutting and morale sapping efficiency drives. Since Pritchard's ambition is to promote workforce health and wellbeing, innovative ways for staff to support colleagues are indeed welcome (doi:10.1136/bmj.n1812). ${ }^{19}$
Innovation also sometimes comes with a red flag, such as in drug regulation. Almost half the drugs approved by the US Food and Drug Administration's accelerated pathway have not been shown to be clinically effective (doi:10.1136/bmj.n1898). ${ }^{20}$ Now the UK's medicines regulator, the Medicines and Healthcare Products Regulatory Agency, is promising faster, more innovative approval processes despite a $20 \%$ staff cut forced by the loss of EU budgets (doi:10.1136/bmj.n1918). ${ }^{21}$ It's unclear how job losses square with demands for better regulation of devices, where patients struggle to have their concerns taken seriously. ${ }^{22}$ By contrast, the weighting of qualitative patient experience in the revised guidance from the National Institute for Health and Care Excellence on chronic fatigue syndrome has led to controversy (doi:10.1136/bmj.n1937). ${ }^{23}$ Three members of NICE's guidelines panel have resigned, although the reasons for the resignations have not been disclosed.

Into this summer of our discontent enter Marcus Rashford, professional footballer and social activist. In an open letter in The BMJ Rashford urges health professionals to help tackle child food poverty by encouraging sign-ups to the government's Healthy Start scheme

(https://blogs.bmj.com/bmj/2021/o8/o4/marcusrashford-every-child-deserves-the-best-chance-inlife-here-is-how-health-professionals-can-help). ${ }^{24}$ More broadly, a radical change from government is needed to kickstart a national food strategy (doi:10.1136/bmj.n1865). ${ }^{25}$ And here is where Pritchard's dilemma lies: when caught-as any modern chief executive might find themselves-between government and a professional footballer, the de facto voice of the people, which side do you take if you are a "strong leader in a male world"?

Rimmer A. Amanda Pritchard becomes first woman to lead NHS England BMJ 2021;374:n1930. doi: 10.1136/bmj.n1930 pmid: 34340963

Gregory A. Amanda Pritchard, the new NHS chief: 'My hero? Elizabeth I, a strong leader in a male world.' Times https://www.thetimes.co.uk/article/amanda-pritchard-the-new-nhs-chief-my-hero-elizabeth-i-a-strongleader-in-a-male-world-hq2gjfs7f

3 Oliver D. David Oliver: Is more statutory power for the health secretary to intervene in the NHS wise?BMJ2021;374:n1916doi: 10.1136/bmj.n1916.

4 Gerada C. Clare Gerada: Happy birthday, NHS. BMJ2021;374:n1917. doi: 10.1136/bmj.n1917 pmid: 34344711

5 O'Dowd A. Covid 19: Most patients in England received good or excellent care in hospital, finds analysis. BMJ2021;374:n1935. doi: 10.1136/bmi.n1935 pmid: 34340964

6 Salisbury H. Helen Salisbury: Running on empty. BMJ2021;374:n1915. doi: 10.1136/bmj.n1915 pmid: 34344642

7 Mahase E. General practice needs rescue package to prevent burnout and preserve care, warns RCGP. BM/2021;374:n1913. doi: 10.1136/bmj.n1913 pmid: 34326060

8 Parker M, Bedford H, Ussher M, Stead M. Should covid vaccination be mandatory for health and care staff?BMJ 2021;374:n1903doi: 10.1136/bmi.n1903.

9 Mittelman M. Patient commentary: Protect patients like me-make covid vaccines mandatory for all eligible staff in care settings. BMJ 2021;374:n1921doi: 10.1136/bmj.n1921. 
10 Ahmed N. Commentary: Mandatory covid vaccination blames individual care home workers for government failures. BMJ 2021;374:n1902doi: 10.1136/bmj.n1902.

11 lacobucci G. Life expectancy: White people in England and Wales had worst outcomes before pandemic, data show. BMJ2021;374:n1886. doi: 10.1136/bmj.n1886 pmid: 34315714

12 Chiavaroli L, Danielle L, Amna A, etal. Effect of low glycaemic index or load dietary patterns on glycaemic control and cardiometabolic risk factors in diabetes: systematic review and meta-analysis of randomised controlled trials. BMJ2021;374:n1651doi: 10.1136/bmj.n1651.

13 Taylor R, Ramachandran A, Yancy WS, JrForouhi NG. Nutritional basis of type 2 diabetes remission. BMJ 2021;374:n1449. doi: 10.1136/bmj.n1449 pmid: 34233884

14 Thombs BD, Markham S, Rice DB, Ziegelstein RC. Does depression screening in primary care improve mental health outcomes?BM/2021;374:n1661. doi: 10.1136/bmj.n1661 pmid: 34281908

15 Nguyen J, Ko I, Martinez-Sosa S, Mizoguchi R. Ward based management of behavioural and psychological symptoms of dementia. BMJ2021;374:n1779doi: 10.1136/bmj.n1779

16 Landré B, Fayosse A, Ben Hassen C, etal. Terminal decline in objective and self-reported measures of motor function before death: 10 year follow-up of Whitehall II cohort study. BMJ 2021;374:n1743doi: 10.1136/bmj.n1743.

17 Wise J. Restarting NHS cardiovascular care after covid-19. BMJ2021;374:n1861. doi: 10.1136/bmj.n1861 pmid: 34315712

18 Pritchard A. Twitter. 2 Aug 2021. https://twitter.com/AKPritchard2/status/1422239492359041024.

19 Rimmer A. How can I keep in touch with colleagues?BMJ 2021;374:n1812 doi: 10.1136/bmj.n1812 pmid: 34344713

20 Mahase E. FDA allows drugs without proven clinical benefit to languish for years on accelerated pathway. BMJ 2021;374:n1898. doi: 10.1136/bmj.n1898 pmid: 34326042

21 lacobucci G. MHRA to shed a fifth of its workforce in post-Brexit cost cutting drive. BMJ 2021;374:n1918. doi: 10.1136/bmj.n1918 pmid: 34330736

22 O'Donohue S. The ripples of trauma caused by severe pain during IUD procedures. BMJ 2021;374:n1910.

23 Torjesen I. Exclusive: Four members of NICE's guideline committee on ME/CFS stand down. BM 2021;374:n1937. doi: 10.1136/bmi.n1937 pmid: 34344688

24 Rashford M. Every child deserves the best chance in life, and here is how health professionals can help. BMJ Opinion. 4 Aug 2021. https://blogs.bmj.com/bmi/2021/08/04/marcus-rashfordevery-child-deserves-the-best-chance-in-life-here-is-how-health-professionals-can-help.

25 Adams J. National food strategy: what's in it for population health?BMJ 2021;374:n1865. doi: 10.1136/bmj.n1865 pmid: 34315780 